\title{
The evolution of the area between Valea Chinteni and Valea Calda after the works done so as to prevent the soil erosion
}

\author{
Violeta-Elena Retegan \\ Department of Geography \\ Cluj-Napoca, Romania \\ violetaretegan@yahoo.it
}

\begin{abstract}
The area studied is situated on the left hill of the Somesul Mic river, along Cluj -Napoca municipality and is deliminated at north and east by the watershed area, which separates the hydrografic subbasin Valea Calda, at south of agricultural road which separates the hill of the meadow Somesul Mic and at west the border of the orchard IAS, The Agricultural State Enterprise Cluj.The area is called Sfantul Gheorghe Hill the omonim peak at the east margin, and Tigla Hill, at east. In 1986 The Institute of Studies and Projects for Landing Improvements applied a plan for preventing the soil erosion on a surface of 600 hectares in the limits mentioned [1]. Among these, 300 hectares represented the arranging of terraces, 200 hectares the arranging the slid lands and $\mathbf{1 0 0}$ hectares of drainages on hills. The works executions of preventing the soil erosion wanted as a finallity the reductions of soil yearly looses, the possibility of applying of some suitable agrotechniques in fruit trees plantations which were going to establish. The arranging of slid landings was made by modelling, the removal moisture excess, terracing, grassing or planting and had the purpose to reduce in the economic circuit many land surfaces. The removal of water excess through drainages was accomplished for a proper development of the future fruit trees plantations, as well as to offer the possibility of executation by fruit trees agrotechnique, all year round. Firstly, the purpose of this study is to analyse the temporary evolution on a period of 30 years, the work efficiency of arranging the slope arranged in 1986. The estimation of work efficiency in that moment was made through a comparative analyse, morfometric and morfologic of land slidings and of erosion forms in deepth on the hills. Secondly, the study analyzes the vulnerability of the elements exposed to risk, at landslidings from this complex, especially of the dwellings and of those with a public destination, of the road infrastructure and of the agricultural lands.
\end{abstract}

Keywords - territory arranging; soil erosion; landslidings; terraces; modelling; vulnerability; torrents

\section{PREMISES}

The study is based on the following premises: the south slope geomorfology of the hill Sfantu Gheorghe was deeply studied along the time, as the bibliographic sources show $[2,3,4] ; 30$ years ago, the territories destinations of this complex is predominant agricultural and the territory arranging plans had especially measures destinated to agricultural arrangements.; In the last years, it has been shown a fast expansion of Cluj-Napoca municipal [5], inclusive on the north hill of Somesul Mic River, at the base of the hill towards the interfluves, as well as along the hill base, towards the eastern outskirts of the city.

\section{QUESTIONS}

The questions raised are: how the landslidings evolved and how the hill evolved after the arrangement made in 1986; how many of the elements built are placed in areas with an acceptable risk and how many are situated in areas with high risk from the point of view of hills stability $[6,7$, 8].

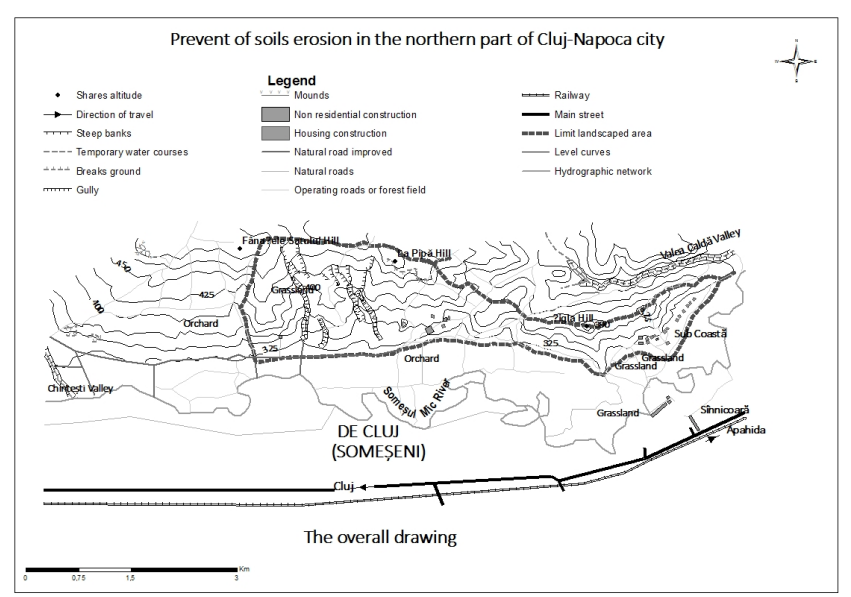

Fig. 1. Prevent of soils erosion in the northern part of Cluj-Napoca, 1986 




Fig. 2. Prevent of soils erosion in the northern part of Cluj-Napoca, 2015

\section{REFERENCES}

[1] „Preventing the soil erosin on the northern part of Cluj-Napoca municipality”, Project no.6855 of the Institute of Studies and Projects for Landing Improvements within Ministry of Agriculture, The general direction of land reclamation end economic agricultural buiding, Cluj-Napoca, 1986, unpublished.

[2] T. Morariu and I.Mac, , Geomorphological regionalization of the territory of Cluj and surroundings”, Studia Universitatis „BabeşBolyai”, series Geology-Geography, vol.2, p. 75-88, 1967.

[3] V. Surdeanu, D. Goțiu, I. Rus and A. Crețu, „Geomorphology applied in the urban area of Cluj-Napoca municipality, Journal of geomorphology, vol. 8, pp. 25-34, 2006.

[4] S.L. Poszet, „Applied geomorphology study in urban area ClujNapoca”, PhD thesis, 2011.

[5] I. Hărănguș, „,The accessibility of Cluj-Napoca to public transport”, 14th National Student Scientific Session, U.T. Press, Cluj-Napoca, 2015, p.526-532.

[6] D. Goțiu, „Risk geomorphological processes in Hațeg Land”, PhD, 2007.

[7] D. Goțiu and V. Surdeanu, „Fundamental concepts in the study of natural hazards”, Cluj University Press, Cluj-Napoca, 2007.

[8] M. Licurici, O. Ionuș, L. Popescu, A. Vlăduț, S. Boengiu and D. Simulescu, „Assessment and reduction of natural and technological hazards”, Universitaria Press, Craiova, 2013. 